\title{
The Effect of Campus Environment towards Students' Entrepreneurship Attitude and Behavior
}

\author{
Neiny Ratmaningsih \\ Department of Social Science Education \\ Universitas Pendidikan Indonesia \\ Email: neinyupi@yahoo.com
}

\begin{abstract}
The majority of education world bring forth a "worker generation", whom became workers and labourers in several Asian countries. Similar conditions worsen with the immigration of young experts and intellectuals to make a living in another hemisphere. Contribution to advance the nation's children are not in accordance with professionalism. This study aims to: (1) obtain descriptive of the campus environment, entrepreneurship attitudes and behavior of student, (2) determine how much influence the campus have towards students' entrepreneurship attitudes and behavior. This study uses a quantitative approach with structural methods or Structural Equation Modeling (SEM). Data were collected by questionnaire, attitude scales and literature. The population in this study were students of the Faculty of Education of Social Sciences with a sample of 250 people. The results showed that: 1) Campus environment has a positive effect on students' entrepreneurship attitude and behavior. This finding is consistent with the initial hypothesis which states that the campus environment has a significant positive effect on the students' entrepreneurship attitude and behavior. 2) The conceptual model of cultivating students' entrepreneurship attitudes and behavior in college implement learning and teaching strategies of Social Studies Education with entrepreneurship concept.
\end{abstract}

Keywords - Campus Environtment, Enterpreneurship Attitudes and Behavior

\section{INTRODUCTION}

The fundamental paradox lies in the solidness of educational foundation in creating the next generation of innovators, creative, skillful, character and capable people. Indications of individual quality gap from their cultural background also trigger national problems. Cognitive accentuation priority helped to give birth to generations of memorizing, ssubmissive, homogeny perspective, and low quality. The majority of education world is now bringing forth a "worker generation", whom became workers and labourers in several Asian countries. Our graduates are only prepared to look for jobs, but are unprepared to create new jobs with innovation. While other ASEAN countries that lack natural resources, are able to create competent and professional human resources. The state of our graduates has an increasingly alarming symptoms of greater unemployed high school and college graduates and may cause these graduates to be unemployed [1].
A nation will progress if the amount of entrepreneur is at least $2 \%$ of the population. This is consistent with what was said by the US sociologist [2] decades ago; a country needs entrepreneurs at least $2 \%$ of their population in order to become prosperous. While Syarif Hasan (former Minister of Cooperatives and SMEs, in the event the University of Ciputra Entrepreneurship Online in Ciputra World, South Jakarta, on Monday, 17 February 2014) stated that Indonesia only has $1.56 \%$ of from total 240 million citizens, which means that for us to reach $2 \%$ we still need $0: 44 \%$ or about 960,000 people. Compared to that, in 2014 Singapore's entrepreneur amount is $7.2 \%$, USA's $12 \%$, Malaysia's $4 \%$, Thailand's $4.1 \%$, and Japan's $10 \%$ of the population.

Improving the quality of education is the right and actual choice. But the government does not have the commitment and seriousness to education yet. The main task of our education world is to raise young, talented innovators whom has an oriented priority on vision and mission development. This is where the entrepreneurship foundation becomes urgent and it is expected to contribute to economic development in Indonesia. The embodiment of entrepreneurship attitudes and behavior of young people has been increasingly needed to develop interest in entrepreneurship. The attitude and behavior of entrepreneurship includes three important things: innovation, capability of reading opportunities, and posession of vision and mission [3]. These three pillars can be a positive contribution to advance the quality of education. The quality of education determines the character of a nation in the global competition arena, and therefore to cultivate the younger generation requires in-formal, formal and non-formal education.

Our education still holds a serious problem, because it has not been empowering all aspects of learning. Cognitive priority often forgot aspects of skills and character. The result is that the developments of intellectual, psychological and character maturity are unbalanced. Creative learning directs students to explore learning resources as wide as possible into solutions. Students serve as subjects and centers of learning. The role of educators is to facilitate students in developing all their intelligence and potential. Measures of students' success is not the achieved grade but the process of learning and creativity. The success is determined by the creativity and selfdevelopment process that runs in the educational process. It is very naive, when the success and quality of students is only measured by the value of the final cognitive and theory exam. 
The orientation of the business perspective can be applied in formal education. Business perspective is not only directed to the knowledge of the business world, but more on empowering students to become risk takers. Students are directed to be ready in facing global challenges, with possibilities of various solutions. It also meant for our students to be independent and able to create new opportunities and new jobs. The hope is that giving students the ability to become a player in global competition, with their quality and potential.

In line with the national function of education, to develop the ability, character, and civilization to create a dignified nation in order to give education and develop students' potentials to become faithful, noble, healthy, knowledgeable, skilled, creative, independent, citizens [4]. The above function and purpose shows that in addition to quantitative indicators, there are other critical qualitative indicators of educational outcomes to be achieved, such as: faith to God, noble, healthy, knowledgeable, skilled, creative, independent, democratic, and responsible. Those qualitative indicators relate to the character formation of students and are associated with the formation of entrepreneurship attitudes and skills, so that they are able to compete, posess ethics, morals, and manners, and have the entrepreneurship attitudes and skills.

Based on the research found that the majority of respondents felt that soft skills are very useful for social interaction and career advancement [5]. However, they do not think that these skills contribute considerably to their academic performance. Five important soft skills identified within the student is: teamwork and collaboration, decision making, problem solving, time management and critical thinking skills. The results of the same study, [6] reveals how soft skills complement hard skills, soft skills training in hard skills program is a very effective method and efficient to achieve both by pulling on teaching specific content and an increase in soft skills. Soft skills fulfill an important role in shaping an individual's personality. It is of high importance for every student to acquire adequate skills beyond academic knowledge of a person.

A study conducted by [7] that includes more than 52 different professions with more than 8,000 managers in the United States identified the employee soft skills as a core competency in almost all professions, even in a technical environment one. This shows that the soft skills greatly affect one's career advancement. Through these studies suggest that the quality of education, including entrepreneurial attitudes and behavior of students is very important to be improved. Therefore, it is important to build a sound entrepreneurship education in principles and methodology education toward developing life skills in learners through an integrated curriculum developed in schools [8].

Referring to the social learning theory of [9] as one of the theories that support social studies education learning to include students' entrepreneurship learning process. This theory is one of the concepts in behaviorism that emphasizes the cognitive component of the mind, understanding and evaluation of the environment. This theory is also called learning observational emphasized on how human behavior is affected by the surrounding environment through reinforcement and replication of our own thinking towards something, and vice versa, that is how our behavior affects the people who are around us and reinforce and open opportunity to be observed by others.

In connection with that, improving the quality of learning and other factors that affect learning outcomes need to be done in a systematic and continuous. Therefore, the author believe that entrepreneurship education will be able to generate a positive perception of the profession as an entrepreneur. This evidence is found equally in primary school, junior or senior high, even universities, that learners in schools that provide education entrepreneurship give a positive perception about entrepreneur profession. This positive perception will give a significant impact to business creation and development of entrepreneurs and new businesses that are indispensable for Indonesia's development.

\section{METHODOLOGY}

The approach used in this study is a quantitative approach to explain the relationship of the variables that influence the students' entrepreneurship attitudes and behavior. This research method used survey methods to explain the causal relationship between variables along with hypothesis testing. The survey used in this study are categorized on survey research conducted for the purpose of the survey sample. The goal is to further explain, that is to study a social phenomena and investigate the relationships of research variables. The characteristics of the method of the survey is that the goal can be descriptive and verificative, explanatory or confirmatory, data were collected from sample that has been determined, variable data research collected by using a collection of specific data; questionnaires [10, [11].

The population in this study were all students of the Faculty of Social Science Education in Education University of Indonesia, which is spread across various Departments and Study Programs, including: the Department of Citizenship Education, Department of History, Department of Geography, Department of Education Social Studies, Education Studies Sociology, Tourism Marketing Management Study Program, Catering Industry Management Studies Program, Resort and Leisure Management Studies Program, Communication Studies, Islamic Education Studies and Survey and Mapping and Geographic Information Studies Program. Total population of students of the Faculty of Social Sciences Education of Education University of Indonesia in 2012 to 2015 of 3393 were filtered through Invitation SNMPTN, SBMPTN, and SMUPI. The sampling technique is done through the stages, namely 1) search for data of students who take an active role and experience as an entrepreneur, and 2) determine the respondents selected to fill out a questionnaire. Distribution of samples of students who have a background of entrepreneurs set as many as 250 people. These samples were taken based on the observations and preliminary data in the field towards an active student as an entrepreneur, whether off-line or on-line entrepreneurship.

Data collection techniques used in this study is SSHA (Survey of Study Habits and Attitudes) scale questionnaire by [12] that had been adjusted with Indonesia local culture. The data obtained are then processed through a process of editing, scoring, data entry, and data analysis. For the analysis of respondent data and categories of respondents used tools AMOS software. Testing the hypothesis in this study using 


\section{Anumests PRESS}

structural equation modeling analysis or commonly called (Structural Equation Model / SEM).

\section{FINDING AND RESULTS}

\section{A. Research Findings}

Campus environment variable is an independent variable that influences the students' entrepreneurship attitudes and behavior. Campus environment variable is composed of two indicators, namely the macro environment and micro environment. Macro environment indicators show how the coaching is done by the campus or campus activities unit concerned in the process of forming entrepreneurship attitudes and behavior. While the micro-environment shows how the coaching is done by lecturer in the classroom.

Below is the percentage of macro environment from the respondents.

TABLE I. FREQUENCY DESCRIPTION ON STUdENT PERCEPTION OF MACRo ENVIRONMENT INDiCATORS

\begin{tabular}{|c|c|c|c|c|c|c|c|}
\hline \multirow[b]{2}{*}{ No } & \multirow{2}{*}{ Statement } & TP & JR & KD & SR & SL & Total \\
\hline & & $\%$ & $\%$ & $\%$ & $\%$ & $\%$ & \% score \\
\hline 1 & $\begin{array}{l}\text { Campus issued a policy through concrete programs relating to } \\
\text { entrepreneurship }\end{array}$ & 1.78 & 15.56 & 43.56 & 23.56 & 15.56 & 11.02 \\
\hline 2 & Campus integrated entrepreneurship learning into lectures & 3.56 & 15.56 & 26.67 & 29.33 & 24.89 & 11.71 \\
\hline 3 & $\begin{array}{l}\text { Campus created a national culture movement and entrepreneurship } \\
\text { training for students }\end{array}$ & 4.44 & 24.00 & 36.44 & 20.44 & 14.67 & 10.41 \\
\hline 4 & in the form of entrepreneurship education and seminar & 2.22 & 16.44 & 40.00 & 27.56 & 13.78 & 10.98 \\
\hline 5 & $\begin{array}{l}\text { Campus provided facility support to entrepreneurship through } \\
\text { apprenticeship }\end{array}$ & 8.89 & 20.44 & 32.00 & 23.11 & 15.56 & 10.38 \\
\hline 6 & $\begin{array}{l}\text { Campus provided facility support to entrepreneurship including business } \\
\text { preparation, capital support, and business assistance }\end{array}$ & 8.00 & 18.67 & 36.44 & 24.44 & 12.44 & 10.34 \\
\hline 7 & $\begin{array}{l}\begin{array}{l}\text { Student Activity Unit (UKM) on campus supported } \\
\text { entrepreneurship activities }\end{array} \\
\text { entudents' }\end{array}$ & 1.78 & 8.00 & 28.89 & 36.00 & 25.33 & 12.32 \\
\hline 8 & Campus created a climate and atmosphere based on entrepreneurship & 6.22 & 16.44 & 30.67 & 30.67 & 16.00 & 10.97 \\
\hline 9 & An example of figures that are successful in entrepreneurship on campus & 5.33 & 12.00 & 23.56 & 34.22 & 24.89 & 11.87 \\
\hline TO & & & & & & & 100 \\
\hline
\end{tabular}

Based on the table 1. it can be seen that the picture indicator that rated highest by respondent's in measuring the dimensions of the micro environment is the support of the Student Activity Unit (UKM) campus on entrepreneurship activities of students with the highest average score of $12.32 \%$, while considered the lowest is support in providing facilities to the campus surrounding the drafting of business entrepreneurship, venture capital support and assistance. Assessment of that indicator is at $10: 34 \%$.

While the percentage of the microenvironment of the respondents can be seen as follows.

TABLE II. FREQUENCY DESCRIPTION ON STUDENT PERCEPTION OF MiCRo ENVIRONMENT INDICATORS

\begin{tabular}{|c|c|c|c|c|c|c|c|}
\hline \multirow[b]{2}{*}{ No } & \multirow[b]{2}{*}{ Statement } & TP & JR & KD & SR & SL & Total \\
\hline & & $\%$ & $\%$ & $\%$ & $\%$ & $\%$ & \% score \\
\hline 1 & Lessons held in the campus environment can shape the students' as a whole & 0.44 & 11.56 & $\begin{array}{l}34.6 \\
7\end{array}$ & 35.56 & 17.78 & 8.21 \\
\hline 2 & Lessons held in the campus are experiential -based learning & 0.00 & 13.33 & $\begin{array}{l}44.0 \\
0\end{array}$ & 30.22 & 12.44 & 7.82 \\
\hline 3 & Lessons held in the campus are real-life based learning & 0.00 & 8.44 & $\begin{array}{l}27.1 \\
1\end{array}$ & 40.89 & 23.56 & 8.69 \\
\hline 4 & $\begin{array}{l}\text { Lessons held in the campus are based on life skills to shape students' } \\
\text { enterpreneurship character }\end{array}$ & 1.33 & 8.44 & $\begin{array}{l}32.4 \\
4\end{array}$ & 36.00 & 21.78 & 8.44 \\
\hline 5 & Lessons held in the campus are focused not only on Business Plan & 3.11 & 9.78 & $\begin{array}{l}34.6 \\
7\end{array}$ & 36.00 & 16.44 & 8.08 \\
\hline 6 & $\begin{array}{l}\text { Lecturers provided example on the education of entrepreneurship value to } \\
\text { students }\end{array}$ & 1.33 & 10.67 & $\begin{array}{l}32.8 \\
9\end{array}$ & 38.67 & 16.44 & 8.20 \\
\hline
\end{tabular}




\begin{tabular}{|c|c|c|c|c|c|c|c|}
\hline \multicolumn{8}{|c|}{ (Table II, cont.) } \\
\hline 7 & $\begin{array}{l}\text { Lecturers are capable of designing integrated entrepreneurship learning values } \\
\text { of to students }\end{array}$ & 3.11 & 13.78 & $\begin{array}{l}38.6 \\
7\end{array}$ & 29.33 & 15.11 & 7.77 \\
\hline 8 & Lecturers are able to understand the concepts of enterpreneurship & 1.78 & 13.33 & $\begin{array}{l}27.1 \\
1\end{array}$ & 40.89 & 16.89 & 8.19 \\
\hline 9 & $\begin{array}{l}\text { Lecturers created creativity and innovation that are beneficial for the } \\
\text { development of the campus }\end{array}$ & 0.89 & 8.44 & $\begin{array}{l}37.7 \\
8\end{array}$ & 36.89 & 16.00 & 8.21 \\
\hline 10 & Lecturers have a sense of entrepreneurship as a source of student learning & 3.11 & 12.44 & $\begin{array}{l}36.4 \\
4\end{array}$ & 30.22 & 17.78 & 7.95 \\
\hline 11 & $\begin{array}{l}\text { The classroom environment gave students the opportunity to be an } \\
\text { entrepreneur }\end{array}$ & 0.44 & 6.67 & $\begin{array}{l}16.4 \\
4\end{array}$ & 41.78 & 34.67 & 9.24 \\
\hline 12 & The classroom environment supported students to become entrepreneurs & 0.89 & 6.22 & $\begin{array}{l}16.4 \\
4\end{array}$ & 43.11 & 33.33 & 9.20 \\
\hline \multicolumn{7}{|c|}{ TOTAL } & 100 \\
\hline
\end{tabular}

The table II shows that the respondents' votes on dimensional picture of the micro environment. Indicators were rated highest in forming the micro environment is the classroom environment gave students the opportunity to be an entrepreneur with the highest average score of $9.24 \%$, while the indicator of the lowest rated by respondents were lecturers are capable of designing integrated entrepreneurship learning values of two students with an average score of $7,77 \%$.

TABLE III. CAMPus ENVIRONMENT VARIABLES CATEGoRy

\begin{tabular}{|c|c|c|c|c|}
\hline No & $\begin{array}{c}\text { Campus } \\
\text { Environment }\end{array}$ & $\begin{array}{l}\text { Total } \\
\text { Score }\end{array}$ & $\begin{array}{c}\text { Average } \\
\text { Score }\end{array}$ & $\begin{array}{c}\% \\
\text { Score }\end{array}$ \\
\hline 1. & Macro Environment & 6849 & 761 & 48.16 \\
\hline 2. & Micro Environment & 9828 & 819 & 51.84 \\
\hline \multicolumn{2}{|c|}{ Total } & 16677 & 1580 & 100.00 \\
\hline
\end{tabular}

Based on the table III shows that of each of the dimensions that make up the campus environment variable, micro environment $(51.84 \%)$ scored higher than the macro environment (48.16\%).

Overview of overall campus environment variables can be viewed in a continuum of the overall review of the respondents' assessment through the calculation process is to find the ideal score in which the highest score multiplied by the number of items multiplied by the number of respondents. Obtained score based on the results of data processing in the campus environment variable is 16.677 or $70.59 \%$ of the ideal score, the scores in continuum can be described as follows:

(16.677)

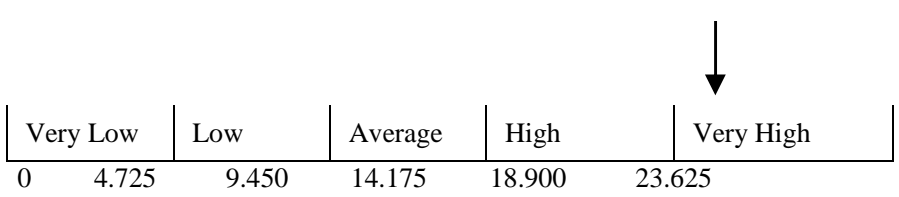

Fig. 1. Variable Continum Value of Campus Environment
Based on the campus environment variables continum value, the total score for these variables is 16.677 are on the continuum line with the very high category.

\section{B. Research Reviews}

1. Influence of Campus Environment Towards Students' Entrepreneurship Attitude and Behavior

Campus environment variable is an independent variable that influences the students' entrepreneurship attitudes and behavior. The role of universities to shape influences the students' entrepreneurship attitudes and behavior may be applied through two strategies namely macro and micro strategies [13]. Macro environment indicators show how the coaching is done by the campus or campus activities unit concerned in the process of forming entrepreneurial attitudes and behaviors. While the micro-environment shows how the coaching is done by lecturers in the classroom. Based on the results of student's perception of the campus environment they feel in the form of support to entrepreneurship show that the dimensions of the micro environment $(51.84 \%)$ scored higher than the macro environment (48.16\%).

Based on data from the percentage of students' perceptions of the micro environment showed that the high creation of a classroom environment which gave students the opportunity to be an entrepreneur with the highest average score of $9.24 \%$. Because each student in Faculty of Social Science Education environment have some compulsory courses that provide the flexibility to increase the potential and talent in entrepreneurship, especially the involvement of students in entrepreneurial activity on campus or in the classroom. One of the compulsory faculty course Social Sciences Education, a general course that provide an understanding regarding the scope of entrepreneurship. In addition, there are also special courses namely entrepreneurship courses owned by each department as a means of motivation for young entrepreneurs.

While the indicator rated lowest by respondents are capable of designing integrated entrepreneurship learning values of two students with an average score of $7,77 \%$. It is caused by while the entrepreneurship integrated subjects already exist, but the lecturers are not yet able to design materials, methods, media/resources and evaluation that are integrated with the values of entrepreneurship. The main obstacle lies in the lack of lecturers accessing up to date material sharing their 
experiences with others in the same field of study. This deficiency may be due to the limited opportunity, or indeed the lack of ability and willingness of lecturers [14].

Micro environment on campus is the smallest environment unit, so that the habituation of entrepreneurship between students and lecturers are more, including interactions of entrepreneurship values in teaching and other academic culture in the classroom. In implementing entrepreneurship valuebased learning lecturers should be able to create 1) learning that shapes a person holistically; 2) learning that evoke the five senses of the student; 3) learning based on experiential learning; 4) a real-life learning; 5) learning based on life skills shaping the entrepreneurship character; and 6) entrepreneurship learning does not only focus on Business Plan [15].

Furthermore, research of [16] on "entrepreneurship and characteristics of the entrepreneurial personality" or interpreted as entrepreneurship personality characteristics and their impact on the changes in the entrepreneur relationship. According to empirical findings, being and acting as a good entrepreneur could be seen from the learning process in educational environments, which in turn has an effect on the entrepreneurship personality characteristics. Entrepreneurship learning are encouraging on solving problems and control by other forces who declined since the early phases. Changes in entrepreneur relationships with others is also observed to have an effect on the personality characteristics of entrepreneurs.

Data percentage of students' perceptions about the next variable is the macro environment showed high support for the Student Activity Unit (UKM) campus on students' entrepreneurship activities with the highest average score of $12.32 \%$. Macro strategies undertaken at the college level policy to develop the spirit and character of entrepreneurship through real programs so that students are expected to be job creators. College's learning policy includes integrating entrepreneurship into the education curriculum; developing entrepreneurship center at the college; developing Entrepreneurship Student Activity Unit and creating national movement culture and entrepreneurship training for students.

The institution is itself a form of small communities and is viewed as a system of social organization in that it included goals and values, structural sub-systems, and sub-cultural systems [17]. Therefore, a healthy campus environment will be able to build a high entrepreneurship culture. They will have an important role in influencing and shaping entrepreneurship character and independence of a student. Education University of Indonesia itself has contributed in cultivating entrepreneurship for students in college. Here below are programs and institutions that were created by Education University of Indonesia with the aim of guide students as young entrepreneurs.

\section{a) Student Activity Units}

Enterpreneurs Student Activity Unit or Business Community has an important role in shaping the personality of students through entrepreneurship. For example, KOPMA Bumi Siliwangi UPI engaged in entrepreneurship in which have special programs to foster students' entrepreneurial attitudes and behaviors are supported by the Student Cooperative Fund UPI. Various business developed by the student, including a photocopy shop, mini market, stationery shop, food court, and many more.

\section{b) Business Incubator LPPM UPI}

UPI Business Incubator (IBUPI) LPPM UPI is an organization/business education forum under the authority LPPM (Institute for Research and Community Service) UPI. Students can avail the services of the incubator on the development of SMEs in the form of intensive assistance through information, consulting, mentoring business plan, as well as entrepreneurial training.

\section{c) Student Creativity Week Entrepreneurship}

Student Creativity Week program become a yearly routine from the Ministry of Research and Technology of Higher Education in facility the activities of students to get funding for innovative and best entrepreneurship. Students make entrepreneurship proposals with training process for preparing and coaching proposal by the lecturer or by the Institute for Research and Assessment of Intellectual Students (LEPPIM UPI).

\section{d) Student Entrepreneurship Program}

Student Entrepreneurship Program is an instrument to develop the capacity of institutions in higher education who manage and develop entrepreneurship education programs on an ongoing basis. The program is caused by a tendency of college graduates to be job seekers, college graduates who are less able to be creative in difficulties and limitations, and the lack of relevance of learning in college with the environment and the world of work.

All those programs took part and contributed to cultivating entrepreneurial spirits of students in Education University of Indonesia. The participation of the respondents entered in organizations Student Activity Units on campus shows that, among students who do not enter any organization as many as 14 people or $5.6 \%$ indicating that they are more focused on their enterpreneur activities, students who attend organizations are 117 people, or $47 \%$, students which attend the Student Activity Unit as many as 59 people or $23.7 \%$, students who attend BEM REMA as many as 15 people or $6 \%$, students who attend extra-campus as many as 32 or $12.9 \%$, and the students who attend the entrepreneurship organization as many as 12 people or $4.8 \%$.

From the results of these data can be analyzed that out of 250 students, the majority attend organizations both on campus and off-campus organizations. This marks that the student organization has a good personality management quality. Students in organizations are regarded as intellectuals and are expected to not only pass in quantity but also in quality professional output. In line with the goal of higher education as follows: a) the development of students' potential to become a man of faith and piety to God, noble, healthy, knowledgeable, skilled, creative, independent, skilled, competent, and cultured for the sake of the nation; b) produces graduates who master branch of Science and / or Technology to meet the national interests and improving the competitiveness of the nation; c) produces science and technology through research that observe and apply the value of Humanities for the benefit of the nation's progress, and the progress of civilization and welfare of mankind; and d) realization of community service based on reasoning and research works that are beneficial in promoting the general welfare and educating the nation [18].

While the results of the perception of the other respondents, namely the campus' low support in providing facilities 
surrounding the drafting of business entrepreneurship, venture capital support and assistance. Assessment of the indicator is at $10.34 \%$. This illustrates that the intentions of students in entrepreneurship are very high but the campus' support facilities in entrepreneurial activity is very low. Entrepreneurship programs available in the environment illustrated by the survey results is not optimal to have an influence on entrepreneurship activities of students. This is due to a program that supports student entrepreneurship activities in Education University of Indonesia has not been successfully utilized by students of Social Studies Education completely.

Most students of Social Studies Education have a tendency to attend entrepreneurial training outside the campus environment affecting their entrepreneurship intentions. In line with research conducted by [19] to 640 students in the Portugal found that entrepreneurship training has a significantly positive effect on the intention of students to start a business after they graduate from college.

Optimizing the entrepreneurship program at Education University of Indonesia environment needs to be implemented rigorously and professionally. They do not just exist, but their existence should bring a high role in cultivating students' entrepreneurial attitudes and behavior. [15] in his study recommends several pilot schemes for the development of entrepreneurial spirit in college students who now need to be implemented with certain modifications as follows.

- Students must attend entrepreneurship based courses in a structured program, which is done thoroughly in every department or study program to form a Team Teaching.

- At the initial stage, half of the students who are programmed in community service are given the opportunity to take the Business Internship KKN program.

- At a later stage, the amount may be increased in accordance with the results of the evaluation. Business Internship community service program is a mix between KKN and business internship. For that program should be well designed, and debriefing (training, introduction to business case, mentoring, monitoring and evaluation) conducted.

- Students are given the opportunity to help Business Consulting Clinic and Employment (Job-Placement Center) as a medium of learning for students.

- Workshop-Role models can be done by doing the entrepreneurship workshop with a target completion of a business plan. This workshop is accompanied by an exemplary person (successful and experienced entrepreneurs) to provide insight, encouragement to open a business, and help. This example could also be a multi-agency business association, instructors, lecturers or business teacher, a business consulting firm, etc.

- Developing a student union model handled with the professionalism that also functions as a place of entrepreneurial learning.

- Students develop various collaboration with external parties and alumni who are successful in the field of entrepreneurship.

- College established the Entrepreneurial Incubator managed by professionals who function as a laboratory/center business studies. Students can take advantage of the business center facilities for learning entrepreneurship.

\section{Conceptual Model of Cultivating Students' Entrepreneurship Attitudes and Behavior in Higher Education \\ Entrepreneurship Attitude and Behavior does not just show} up, the process of self-internalization obtained from different types of experience and education obtained from various environments. This study proves that the experience and education obtained in the campus environment influence the entrepreneurship attitudes and behaviors. As for all variables expressed in this study, showed that the most dominant is education. Education has largely affect the attitudes and behavior of people, more so a personality of an entrepreneur.

The role of education in motivating students to become entrepreneurs is one of the factors driving the growth of entrepreneurs. The suggestion that someone has more of a streetsmart than book smart means that an entrepreneur prefers to learn from experience (street-smart) compared to learning from books and formal education (book smart) is difficult to be proven as the truth [20]. The cycle that happens is by increasing self-employment of college graduates, it will reduce unemployment, and increase the number of jobs.

[21] objects to this position, according to him, education is crucial to the success of an enterpreneur. He even stated that the first failure of an entrepreneur is for him to rely more on experience rather than education. But he also does not underestimate the meaning of the experience for an entrepreneur, the second source of failure is when an entrepreneur only has an education but poor in field experience. Therefore, the combination of education and experience are key factors that determine the success of entrepreneurs.

Entrepreneurs are people who have the ability to see and assess business opportunities; pooling resources needed to take appropriate action, taking advantage as well as having the nature, character and willingness to realize innovative ideas into real world creatively in order to achieve success/increase revenues. "An entrepreneur is one who creates a new business in if the face of risk and uncertainty for the purpose of achieving profit and growth by identifying opportunities and assembling the necessary resources to capitalize on those opportunities " [22].

An effective model innovation in cultivating entrepreneurship attitudes and behavior of in higher education is needed to improve the weaknesses that occur in realizing graduates with low unemployment. The innovation of entrepreneurship education in universities in their implementation could not be apart from the constraints including: 1) less supportive higher education policy; 2) inadequate learning infrastructure (media, tools and learning resources (books); 3) low and uneven quality of lecturers in the implementation of learning entrepreneurship innovation; 4) the condition of the student (student background, motivation to learn, the reading culture) are less supportive; 5); costs and inadequate funding; 6) time constraints; 7) the support of parents, communities and institutions as a source of learning; 8) the clarity of the curriculum and the level of difficulty of the 
material in the curriculum of Social Studies Education in college.

To address gaps in entrepreneurship education model of in higher education between the expectations with the reality, it is a necessary efforts to realize a model of cultivation of entrepreneurship attitudes and behavior in higher education with Social Studies Education learning integrated with entrepreneurship in a more practical and realistic way so that students are more sensitive and responsive to social problems in a rational and responsible way, promote tolerance in their own neighborhood or among people, one of which is by using a model of innovative learning and creative. To realize the social studies learning is oriented to the world of business and resources can be preceded by an introduction lectures in teaching entrepreneurial-minded social studies education.

The shape of the innovation needed in realizing the vision of Social Studies Education based on entrepreneurship, namely through the learning and teaching of appropriate and effective including the following.

\section{a) Integration of Entrepreneurship Values in Social Studies} Education

In universities, entrepreneurship courses should be taken by all students from various faculties or programs of study, given that entrepreneurship is directed at mental changes in a person's personality. Quite a lot of colleges are developing specific areas of entrepreneurship education programs, with a goal to produce embryos of young entrepreneurs.

Entrepreneurship education integrated into the Social Studies Education learning process is to internalize the values of entrepreneurship into lessons resulting in gained awareness of the importance of values, the formation of entrepreneurial character and habituation of entrepreneurship values into the students' daily behavior through the process learning taking place both inside and outside the classroom. All students of the Faculty of Education of Social Sciences who has received their education Social Studies Education courses indirectly acquired a cultivated model of entrepreneurship attitudes and behavior intensively and efficiently.

Basically, learning activities in Social Studies Education in addition to having a student master the targeted competencies (material), are also well designed and carried out to make the students get to know, realize/care, the values of entrepreneurship. This step is done by integrating the values of entrepreneurship into social studies education learning in the entire course of Education Faculty of Social Sciences. This integration steps can be done at the time of presenting the material, through learning methods as well as through the scoring system.

The steps of learning entrepreneurship-minded Social Studies Education who used the power in giving effect to the formation of entrepreneurship attitudes and behaviors:

First, a meaningful social studies education learning (when they are meaningful) is intended for faculty and students. Teaching methods already constructed by lecturers must be absorbed to students' social understanding. Implementation could begin by encouraging students through induced questions to connect the idea of previous knowledge with entrepreneurship concepts, objectives and benefits. Thus, a meaningful social studies education learning by [23] were able to leave the practice room for the "students learn the connected networks of knowledge, skills, beliefs, and attitudes that they will find useful both in and outside of school. "

Second, an integrated social studies education learning (when they are integrative) is an assertion that the content of social studies education (social sciences and humanities) has a range of material that must be integrated. Integration becomes absolutely necessary because the elements of the curriculum involves important ideas of students to achieve their own targeted competencies. A social studies education learning curriculum integrated with entrepreneurship can provide the human experience related to the entrepreneurial experience of time and space, connecting with the past, associating with the current, and seeing the future. The core focus of the social studies disciplines including teaching materials is very broad because with regard to social phenomena, to the environment, both in the scope of the latest local, national and even global.

Third, social studies-based learning value (when they are value-based) requires a commitment for lecturers that entrepreneurship values inserted in each lesson to be infused by the students. Awareness of the value that was developed to make students care more about the future and social problems. Also described the "powerful social studies teaching with value-based recognition of opposing point of view, respect for well-supported positions, sensitivity to cultural similarities and differences, and commitment to social responsibility action" [24]. Therefore, social studies-based learning value can provide the awareness that builds positive social relationships requires commitment to respect the equality of rights between man and God, man and man, by man and nature.

Fourth, a challenging social studies learning (when they are challenging) according to [25] including a rigorous learning as a core discipline that effect and continue to develop in-depth investigation process on its contents. Forms of stimulants and challenge from lecturers can be facilitated by using a variety of resources related to entrepreneurship, also series of phenomena and controversial issues that arise. In essence, a challenging social studies learning, encourage curiosity, exploration/ experimentation, as well as the activity of student discussion are the spearhead of the success of teaching and learning in the classroom.

Fifth, an active social studies learning (when they are active) is a form of entrepreneurship learning application which uses reflective inquiry and decision-making in addition to the planning and preparation of learning [23]. The term reflective inquiry assumes the type of social studies that teaches learners to learn how they think. Reflective inquiry is very helpful, because learners will be able to increase intellectual ability fully to seek answers through knowledge questions as well as he understands the value contained [26]. Reflective inquiry provides a bridge for learners to apply knowledge to solve problems directly with decision.

\section{b) Entrepreneurship Teaching in Social Studies Education Learning}

In integrating the values of entrepreneurship there are many values that can be instilled in students. If all the values of entrepreneurship has to be instilled with the same intensity on all courses, the planting of the value would be very heavy. Therefore, planting the values of entrepreneurship is done gradually by selecting a number of principal value as the 
starting base for the cultivation of other values. Furthermore, our core values are integrated in the social studies education material. Thus the social studies education can focus on planting certain basic values that are closest to the characteristics of social studies education subjects. Basic values of entrepreneurship education courses integrated in social studies education at the first step there are six (6) the following principal values: independence, creative risk-taking, leadership, orientation of action and hard work.

Integration of entrepreneur education courses in Social Science Education implemented from planning, implementation, and evaluation. In the planning stage, unit show lecture and Syllabus is designed to load and facilitates learning activities to integrate the values of entrepreneurship. How to create a syllabus that is integrated with entrepreneurship values are conducted by adapting existing syllabus with adding one column in the syllabus to accommodate the entrepreneurship values. Meanwhile, the SAP (Unit Show Lecture) is prepared with an integrated entrepreneurship values conducted by adapting the existing SAP by adding the material, learning steps or appraisal with entrepreneurship values .

Learning principles used in the development of entrepreneur education sought that the students recognize and accept the values of entrepreneurship as their own and are responsible for the decisions taken through the stages of familiarizing options, assessing options, determining the establishment, and thus introduces a value corresponding to their own self. With this principle, students learn through the process of thinking, being, and doing. The third process is intended to develop the ability of students to carry out activities related to the entrepreneurship values.

Integrating the entrepreneurship values in unit show lecture and syllabus can be done through the following steps:

- Assessing the competence outcomes generated to determine whether the values of entrepreneurship is included therein.

- Lists the entrepreneurship values that have been listed in the competency outcomes and objectives of the course.

- Develop a learning step for active learners that allows them to have the opportunity to integrate values and show it in behavior.

- Incorporate entrepreneurship values-integrated active learning steps into unit show lecture.

- Incorporate a medium of learning and reference resources related to entrepreneurship.

Through education and experience gained from the process of entrepreneurship teaching, it is hoped the students can continue after graduating from college, so that successful entrepreneurs whom can create jobs and take employees would appear. According [15] cultivation of the spirit of entrepreneurship in students is expected to motivate students to be able to perform activities of entrepreneurship. Being graduates who have an entrepreneurship mind means having insight and knowledge, managerial capability in managing and developing the organization, willingness to become the initiator of various activities in the community, as well as the ability to capture a wide range of opportunities to improve performance or create work that is useful for private and public.

\section{CONCLUSION}

Results of testing the hypothesis states that the campus environment has positive influence on students' entrepreneurship attitudes and behavior. Campus environment becomes the deciding factor for the personality development of the students can move on to higher education, work or entrepreneurship. A higher position at the level of formal education, so that the real contribution is required in forming students' entrepreneurship attitudes and behavior. Campus environment variables include macro strategies and micro strategies; whereby micro strategy was said to contribute more than in the macro environment.

Micro Strategies is at the level of classroom learning, especially entrepreneur learning whose characteristics are 1) learning that shape human in a holistic manner; 2) learning that evoke the five senses of the student; 3) learning based on experiential learning; 4) real-life learning; 5) learning that is based on life skills to form entrepreneurial character; and 6) learning entrepreneurship not only focused on Business Plan. While the macro strategy at the policy level are universities that are given the duty and responsibility to develop the entrepreneurship spirit and character through real programs so that students are expected to be job creators. Colleges' learning policies include integrating entrepreneurship into the curriculum of higher education; developing entrepreneurship center at the college; and creating a national and culture movement of entrepreneurship training for students. Consistent with the Alma theory that the institution is a form of small communities and is viewed as a system of social organization in that it included goals and values, structural sub-systems, and sub-cultural system. Therefore, a healthy campus environment will be able to build a high entrepreneurship culture. They have an important role in influencing and shaping the entrepreneurship character and independence of a student.

Recommendations can be given of the results of this study for students to illustrate how to train independence, develop creativity and innovative attitude, and a process of habituation / acculturation conducted in developing entrepreneurial attitudes and behavior as a form of personality of students in improving the quality of self. Furthermore, college is responsible for educating its students and provide motivation so that they dare to be entrepreneurs. Thus the effective campus management system can be conditioned by the school itself, which among others include the school curriculum, facilities, and teachers/lecturers. This research can be used as fill material for policy makers to improve the effectiveness of lectures at the Faculty of Education Social Sciences in Education University of Indonesia. Similarly, it can be used as an input for the government and higher education institutions in an effort to cultivate and develop education in producing human resources whom is superior in knowledge, posessing entrepreneurship attitudes and skills, thus becoming independent youth.

\section{ACKNOWLEDGMENT}

Thanks for Department of Social Science Education, Indonesia University of Education.

\section{REFERENCES}

[1] Tilaar H.AR. Beberapa Agenda reformasi Pendidikan Nasional. Jakarta: Tera Indonesia, 1999, p. 162. 
[2] Mc. Clelland, David C. The Achieving Society. New York: D. Van Nostrand Company, Inc, 1961.

[3] Ciputra. Quantum Leap $1^{\text {st }}$ ed. Jakarta: Elex Media, 2008.

[4] Undang-Undang RI No 20 Tahun 2003 Tentang Sistem Pendidikan Nasional

[5] Majid, Zhang Liming, Shen Tong, Siti Raihana. (2012). Importance of Soft Skills for Education and Career Success. International Journal for Cross-Disciplinary Subjects in Education (IJCDSE), Special Issue Volume 2 Issue 2, p. 136.

[6] Schulz, Bernd. The Importance of Soft Skills: Education Beyond Academic Knowledge. Journal of Language and Communication, June 2008

[7] Rubin, R.S. How relevant is the MBA? Assessing the alignment of required curricula and required managerial competencies. Academy of Management Learning \& Education,2009, 8(2), 208-224.

[8] Wibowo, Muladi. (2011), Pembelajaran Kewirausahaan dan Minat Wirausaha Lulusan SMK, Ekplanasi, Volume 6 Nomor 2 Edisi September 2011.

[9] Bandura, A. "Sosial Cognitive Theory: An Agentic Perspective", Annual Review Psychology, Standford University, 2001

[10] Kerlinger, F. N. Asas-asas Penelitian Behavioral. Yogyakarta: Gadjah Mada University Press, 1990

[11] Borg \& Gall. Education Research. New York : Allyn and Bacon, 2003

[12] Brown, W. F. \& Holtzman, W. H. Manual Survey of Study Habits and Attitudes. New York: The Psycholigical Corporation, 1967.

[13] Lupiyoadi, Hamdani. Manajemen Pemasaran Jasa, Edisi Kedua. Jakarta : Penerbit Salemba Empat, 2006

[14] Departemen Pendidikan Nasional Direktorat Jendral Pendidikan Tinggi.. Peningkatan Kualitas Pembelajaran. Jakarta: Direktorat Pembinaan Pendidikan Tenaga Kependidikan Dan Ketenagaan Perguruan Tinggi, 2005, p. 16.
[15] Siswoyo. Pengembangan Jiwa Kewirausahaan di Kalangan Dosen dan Mahasiswa. Jurnal Ekonomi Bisnis, Tahun 14, Nomor 2, Juli 2009

[16] Littunen, H. "Entrepreneurship and characteristics of the entrepreneurial personality". International Journal of Entrepreneurial Behavior and Research, 2015, Vol. 6 Iss 6 pp. 295-310. Tersedia pada: http://dx.doi.org/10.1108/13552550010362741

[17] Alma, Buchari.. Kewirausahaan. Bandung: Alfabeta, 2009, p. 23.

[18] Undang-Undang Nomor 12 Tahun 2012 Tentang Pendidikan Tinggi.

[19] Gerry. C, Susana. C. \& Nogueira. F.. Tracking Student Entrepreneurial Potential: Personal Attributes and the Propensity for Business Start-Ups after Graduation in a Portuguese University. International Research Journal Problems and Perspectives in Management, 2008, 6(4): 45-53.

[20] Basrowi. Kewirausahaan Untuk Perguruan Tinggi. Bogor: Ghalia Indonesia, 2011, p. 78.

[21] Churchill, N.C. \& Lewis, V.L.. 'Entrepreneurship research: directions and methods', in D.L. Sexton \& R.W. Smilor eds The Art and Science of Entrepreneurship, Ballinger, Cambridge, Massachusetts, 1986, pp. 333365.

[22] Zimmerer et. Kewirausahaan dan Manajemen Usaha Kecil. Edisi 5, Buku 1. Jakarta : Salemba Empat., 2008

[23] National Council for the Social Studies. Curriculum Standard for Social Studies: Expectation of Excellece Washington, 1994, 12.

[24] Jarolimek, J \& Parker. Social Studies Elementary Education $9^{\text {th }}$ Ed. New York: Mac Millan Publishing Co, 1993, p. 217.

[25] Brophy. J. \& Alleman, J. (1996). Powerful Social Studies for Elementrary Studies. Florida: Harcourt Brace \& Compeny

[26] Woolever, R \& K.P. Scott. (1988). Active Learning in Social Studies Promoting Cognitive and Social Growth. Glenview Illinois Scott, Foresinan and Company, 1996. 